\title{
Microbial respiration per unit microbial biomass depends on litter layer carbon-to-nitrogen ratio
}

\author{
M. Spohn \\ Department of Soil Ecology, Bayreuth Center of Ecology and Environmental Research (BayCEER), \\ University of Bayreuth, Bayreuth, Germany \\ Correspondence to: M. Spohn (marie.spohn@uni-bayreuth.de)
}

Received: 3 September 2014 - Published in Biogeosciences Discuss.: 24 October 2014

Revised: 10 January 2015 - Accepted: 12 January 2015 - Published: 10 February 2015

\begin{abstract}
Soil microbial respiration is a central process in the terrestrial carbon (C) cycle. In this study, I tested the effect of the carbon-to-nitrogen $(\mathrm{C}: \mathrm{N})$ ratio of soil litter layers on microbial respiration in absolute terms and per unit microbial biomass C. For this purpose, a global data set on microbial respiration per unit microbial biomass $\mathrm{C}$ - termed the metabolic quotient $\left(q \mathrm{CO}_{2}\right)$ - was compiled from literature data. It was found that $q \mathrm{CO}_{2}$ in the soil litter layers was positively correlated with the litter $\mathrm{C}: \mathrm{N}$ ratio and was negatively correlated with the litter nitrogen $(\mathrm{N})$ concentration. The positive relation between $q \mathrm{CO}_{2}$ and the litter $\mathrm{C}: \mathrm{N}$ ratio resulted from an increase in respiration with the $\mathrm{C}: \mathrm{N}$ ratio in combination with no significant effect of the litter $\mathrm{C}: \mathrm{N}$ ratio on the soil microbial biomass $\mathrm{C}$ concentration. The results suggest that soil microorganisms respire more $\mathrm{C}$ both in absolute terms and per unit microbial biomass $\mathrm{C}$ when decomposing $\mathrm{N}$-poor substrate. The reasons for the observed relationship between $q \mathrm{CO}_{2}$ and the litter layer $\mathrm{C}: \mathrm{N}$ ratio could be microbial $\mathrm{N}$ mining, overflow respiration or the inhibition of oxidative enzymes at high $\mathrm{N}$ concentrations. In conclusion, the results show that $q \mathrm{CO}_{2}$ increases with the litter layer $\mathrm{C}: \mathrm{N}$ ratio. Thus, the findings indicate that atmospheric $\mathrm{N}$ deposition, leading to decreased litter $\mathrm{C}: \mathrm{N}$ ratios, might decrease microbial respiration in soils.
\end{abstract}

\section{Introduction}

Large amounts of organic carbon (C) are transformed, stored, and respired by microorganisms in soil. Hence, gaining insight into the factors controlling the respiration rate per unit soil microbial biomass is crucial for understanding the terres- trial $\mathrm{C}$ cycle. The respiration rate per unit microbial biomass $\mathrm{C}$ - termed the metabolic quotient $\left(q \mathrm{CO}_{2}\right)$ - is used as a measure for the ecophysiological status of soil microorganisms (Anderson and Domsch, 1993). Although a large number of studies on $q \mathrm{CO}_{2}$ have been published (reviewed by Brookes, 1995; Bastida et al., 2008; Anderson and Domsch, 2010), little is known about how $q \mathrm{CO}_{2}$ is affected by soil $\mathrm{C}: \mathrm{N}: \mathrm{P}$ stoichiometry.

The soil microbial biomass shows a relatively well constrained stoichiometry similar to the Redfield ratio found for planktonic biomass (Redfield, 1934). Although the stoichiometry of individual phylogenetic groups may vary, the molar $\mathrm{C}: \mathrm{N}$ ratio of the soil microbial biomass at a global scale converges towards 6-8 (Cleveland and Liptzin, 2007; $\mathrm{Xu}$ et al., 2013). The $\mathrm{C}: \mathrm{N}$ ratio of soil litter layers is in the range of 12-80 (Berg and McClaugherty, 2003). Thus, microorganisms decomposing litter with a high $\mathrm{C}: \mathrm{N}$ ratio are confronted with a surplus of $\mathrm{C}$ in relation to $\mathrm{N}$. Compared to other ecosystems, microorganisms in forests face extreme substrate imbalances since the $\mathrm{C}: \mathrm{N}$ ratios of woody plants are extremely high compared to the microbial biomass $\mathrm{C}: \mathrm{N}$ ratio. While, for example, in phytoplankton and macroalgae the $\mathrm{C}: \mathrm{N}$ ratio amounts to approximately 10 , woody plants have a $C: N$ ratio of up to 400 (Cebrian, 1999; Sterner and Elser, 2002).

When growing on $\mathrm{N}$-poor substrate, microorganisms have not enough $\mathrm{N}$ to build up as much biomass as the $\mathrm{C}$ concentration would allow. Thus, it has been argued that microorganisms can dispose of $\mathrm{C}$ via overflow respiration as $\mathrm{CO}_{2}$ to make the substrate meet their nutritional demands (Manzoni et al., 2008, 2010; Sinsabaugh et al., 2013). Overflow respiration, i.e., respiration without the production of energy, has 
been shown to occur in several microbial species in laboratory incubations (Russell and Cooks 1995; Teixeira de Mattos and Neijssel, 1997; Vemuri et al., 2006). The relevance of microbial overflow respiration in ecosystems has recently been questioned by several studies. Firstly, it has been argued that, in order for $\mathrm{C}$ to be disposed of via the respiratory chain, $\mathrm{N}$ for the proteins of the respiratory chain has to be invested, and therefore it might be more beneficial for microorganisms to dispose of excess $\mathrm{C}$ by releasing dissolved organic carbon (DOC) (Hessen and Anderson, 2008). Secondly, it has been pointed out that the energy lost by disposing of $C$ could be invested into storage, antiviral defense or other processes, which increase the fitness of the organism (Hessen and Anderson, 2008; Hessen et al., 2013). Hence, while overflow respiration has been shown to occur in laboratory incubations and seems to be likely from a stoichiometric perspective, the relevance of this process in ecosystems is still under discussion.

The objective of this study was to use data of published studies on $q \mathrm{CO}_{2}$ in soil litter layers to learn about how litter $\mathrm{C}: \mathrm{N}$ stoichiometry affects the respiration rate per unit decomposer biomass. Following stoichiometric theory, I tested the hypothesis that $q \mathrm{CO}_{2}$ increases with litter $\mathrm{C}: \mathrm{N}$ ratio and decreases with litter $\mathrm{N}$ concentration. For this purpose, data from the literature on $q \mathrm{CO}_{2}$ in soil litter layers and on litter layer properties were compiled.

\section{Material and methods}

Literature searches were conducted using Google Scholar, Web of Science, and Scopus in November and December 2013. I searched for the words "metabolic quotient" in combination with the following terms: "litter decomposition", "litter layer", "leaf decomposition", "needle decomposition", "microbial activity", "forest floor", "microbial respiration", "tropical forest", "temperate forest", "boreal forest", "mediterranean forest", and "plantation".

Based on the literature search, I selected studies that reported $q \mathrm{CO}_{2}$ measured in laboratory incubations on litter collected from the soil litter layer of forests, tree and palm plantations, and heathlands. Studies that mixed litter with mineral soil were excluded because it is assumed that stabilization of the soil organic matter by sorption and aggregation possibly obscures relations between element concentrations and $q \mathrm{CO}_{2}$. If results for different treatments were reported, only the data for the control treatment were extracted. If time series were reported, I only extracted the first data point of the series in order to avoid pseudoreplication. In order to prevent confounding results due to different methods, the following criteria were applied for data selection: $q \mathrm{CO}_{2}$ had to be reported in unambiguous units as the respiration rate per unit of microbial biomass $\mathrm{C}$, basal respiration had to be determined during incubations based on $\mathrm{CO}_{2}$ measurements via gas chromatography or titration (but not, for exam- ple, $\mathrm{O}_{2}$ consumption), and the microbial biomass $\mathrm{C}$ had to be determined by means of the fumigation-extraction method. Additionally, the studies had to report either the $\mathrm{C}: \mathrm{N}$ ratio of the litter or both the $\mathrm{C}$ and $\mathrm{N}$ concentration. Besides the metabolic quotient, microbial biomass $\mathrm{C}\left(\mathrm{C}_{\mathrm{mic}}\right)$, basal respiration, and the $\mathrm{C}: \mathrm{N}$ ratio of the litter, the following parameters were collected if reported in the studies: latitude and mean annual temperature of the study site, classification of the litter layer, litter $\mathrm{pH}$, plant species from which the litter was derived, microbial biomass $\mathrm{N}\left(\mathrm{N}_{\text {mic }}\right)$, litter $\mathrm{P}$, microbial biomass $\mathrm{P}$, and temperature and soil litter layer water content at which the respiration measurement had been performed. If data were reported in the form of graphs, numbers were extracted using the open-source software DataThief (Tummers, 2006).

Units were converted to obtain microbial biomass $\mathrm{C}$ in $\mathrm{mg}(\mathrm{g} \text { litter })^{-1}$, basal respiration in $\mu \mathrm{g} \mathrm{CO}_{2}-\mathrm{C}$ (g litter $\mathrm{C})^{-1} \mathrm{~h}^{-1}, q \mathrm{CO}_{2}$ in $\mu \mathrm{g} \mathrm{CO}_{2}-\mathrm{C}(\mathrm{mg} \text { microbial C })^{-1} \mathrm{~h}^{-1}$, and the $\mathrm{C}: \mathrm{N}$ ratio in $\mathrm{mol} \mathrm{mol}^{-1}$. For all analyses including latitude, only the degree of latitude was considered, but no differentiation between the Southern and Northern Hemisphere was made. The Pearson's correlation coefficients were calculated, and the significance of the correlation was tested by means of the Pearson test. In order to evaluate the influence of the incubation temperature and the soil water content on $q \mathrm{CO}_{2}$, the following linear regression models were fitted:

$$
\begin{aligned}
q \mathrm{CO}_{2} & =a_{1} \times \mathrm{C}: \mathrm{N} \text { ratio }+\varepsilon, \\
q \mathrm{CO}_{2} & =b_{1} \times \mathrm{C}: \mathrm{N} \text { ratio }+b_{2} \times \text { temperature }+\varepsilon, \\
q \mathrm{CO}_{2} & =c_{1} \times \mathrm{C}: \mathrm{N} \text { ratio }+c_{2} \times \text { temperature }+c_{3} \\
& \times \text { soil water content }+\varepsilon,
\end{aligned}
$$

where $a_{i}, b_{i}$, and $c_{i}$ are coefficients and $\varepsilon$ is the error term. Furthermore, I fitted a linear model with all litter properties and the latitude of the study site of the form

$$
\begin{aligned}
q \mathrm{CO}_{2} & =d_{1} \times \mathrm{C}: \mathrm{N} \text { ratio }+d_{2} \times \text { temperature }+d_{3} \\
& \times \text { soil water content }+d_{4} \times \mathrm{C}+d_{5} \times \mathrm{N}+d_{6} \\
& \times \mathrm{C}_{\text {mic }}+d_{7} \times \mathrm{N}_{\text {mic }}+d_{8} \times \text { latitude }+\varepsilon,
\end{aligned}
$$

where $d_{i}$ are coefficients and $\varepsilon$ is the error term. All data analysis was conducted in R (R Core Team, 2013).

\section{Results}

Fourteen studies were found that met the above-mentioned criteria, resulting in 48 observations. The studies covered the tropical, temperate, and boreal climate zone, and included data on $q \mathrm{CO}_{2}$ measured on litter derived from seven tree genera. Additionally, two studies reported data on litter of mixed forests with non-characterized species composition, and two studies reported results on litter derived from a palm and legumes and a forb (Table 1).

$q \mathrm{CO}_{2}$ was positively related to the $\mathrm{C}: \mathrm{N}$ ratio of the litter (slope $=0.14, r=0.78, p<0.001$; Fig. 1 ) and negatively 
Table 1. References considered in the analysis together with the latitude of the study site, the plant genus from which the litter was derived, and the number of data points obtained from each reference.

\begin{tabular}{lllc}
\hline Reference & Latitude & Plant & Data points \\
\hline Chang and Trofymow (1996) & $50^{\circ} \mathrm{N}$ & Cedrus & 3 \\
Chapman et al. (2003) & $57^{\circ} \mathrm{N}$ & Pinus & 1 \\
Dinesh et al. (2006) & $10^{\circ} \mathrm{S}$ & Cocos and legumes & 10 \\
Fisk and Fahey (2001) & $44^{\circ} \mathrm{N}$ & Fagus and Betula & 1 \\
Karneva and Smolander (2007) & $66^{\circ} \mathrm{N}$ & Picea, Pinus, Betula & 8 \\
Van Meeteren et al. (2007) & $52^{\circ} \mathrm{N}$ & Forbs & 1 \\
Ndaw et al. (2009) & $21^{\circ} \mathrm{S}$ & Various broadleaf trees, Eucalyptus & 4 \\
Pietikainen and Fritze (1996) & $65^{\circ} \mathrm{N}$ & Picea & 3 \\
Ross and Sparling (1993) & $36^{\circ} \mathrm{S}$ & Pinus & 4 \\
Ross and Tate (1993) & $36^{\circ} \mathrm{S}$ & Fagus & 2 \\
Ross et al. (1996) & $43^{\circ} \mathrm{S}$ & Fagus & 2 \\
Ross et al. (1999a) & $38^{\circ} \mathrm{S}$ & Various trees, Pinus & 4 \\
Ross et al. (1999b) & $61^{\circ} \mathrm{N}$, & Pinus & 4 \\
& $42^{\circ} \mathrm{S}$, & & 1 \\
& $40^{\circ} \mathrm{S}$, & & \\
\hline
\end{tabular}

Table 2. Pearson's correlation coefficient of the latitude of the study site, the $\mathrm{pH}_{\mathrm{H}_{2} \mathrm{O}}$ of the soil litter layer, the $\mathrm{C}$ and $\mathrm{N}$ concentration and the $\mathrm{C}: \mathrm{N}$ ratio of the soil litter layer, the microbial biomass $\mathrm{C}$ and $\mathrm{N}$ concentration $\left(\mathrm{C}_{\text {mic }}\right.$ and $\left.\mathrm{N}_{\text {mic }}\right)$, the microbial biomass $\mathrm{C}: \mathrm{N}$ ratio, the incubation temperature at which the respiration rate was determined (Temp), the respiration rate (Resp), and the metabolic quotient $\left(q \mathrm{CO}_{2}\right)$.

\begin{tabular}{|c|c|c|c|c|c|c|c|c|c|c|c|}
\hline & Latitude & $\mathrm{pH}_{\mathrm{H}_{2} \mathrm{O}}$ & $\mathrm{C}$ & $\mathrm{N}$ & $\mathrm{C}: \mathrm{N}$ & $\mathrm{C}_{\mathrm{mic}}$ & $\mathrm{N}_{\text {mic }}$ & $\mathrm{C}_{\mathrm{mic}}: \mathrm{N}_{\mathrm{mic}}$ & Temp & Resp & $q \mathrm{CO}_{2}$ \\
\hline \multicolumn{12}{|l|}{ Latitude } \\
\hline $\mathrm{pH}_{\mathrm{H}_{2} \mathrm{O}}$ & $-0.39^{*}$ & & & & & & & & & & \\
\hline $\mathrm{C}$ & $0.52^{* * *}$ & -0.16 & & & & & & & & & \\
\hline $\mathrm{N}$ & $-0.51 * * *$ & -0.14 & 0.00 & & & & & & & & \\
\hline $\mathrm{C}: \mathrm{N}$ & $0.38^{* *}$ & 0.17 & $0.51^{*}$ & $-0.81^{* * *}$ & & & & & & & \\
\hline $\mathrm{C}_{\mathrm{mic}}$ & 0.22 & -0.12 & 0.24 & -0.01 & 0.16 & & & & & & \\
\hline $\mathrm{N}_{\text {mic }}$ & -0.01 & 0.25 & 0.13 & -0.20 & 0.22 & 0.08 & & & & & \\
\hline$C_{\text {mic }}: N_{\text {mic }}$ & 0.04 & -0.07 & 0.18 & 0.00 & 0.11 & $0.54^{* * *}$ & $-0.39 *$ & & & & \\
\hline Temp & $-0.42^{* *}$ & $0.39^{*}$ & 0.17 & $-0.38^{*}$ & $0.30^{*}$ & -0.06 & $0.40^{* *}$ & 0.03 & & & \\
\hline Resp & 0.17 & 0.19 & $0.35^{*}$ & $-0.56^{* * *}$ & $0.71^{* * *}$ & $0.52^{* * *}$ & $0.38^{*}$ & 0.07 & $0.33^{*}$ & & \\
\hline$q \mathrm{CO}_{2}$ & 0.13 & $0.36^{*}$ & 0.26 & $-0.72^{* * *}$ & $0.78^{* * *}$ & 0.01 & 0.22 & 0.05 & $0.55^{* * *}$ & $0.64^{* * *}$ & \\
\hline
\end{tabular}

Levels of significance at ${ }^{*} p<0.05,{ }^{* *} p<0.01,{ }^{* * *} p<0.001$

to the litter $\mathrm{N}$ concentration (slope $=0.30, r=-0.72, p<$ 0.001 ; Fig. 2). The positive relation between litter $\mathrm{C}: \mathrm{N}$ ratio and $q \mathrm{CO}_{2}$ resulted from a positive relation between respiration and the $\mathrm{C}: \mathrm{N}$ ratio (slope $=1.47, r=0.71, p<0.001$; Fig. 3), and no effect of the litter $\mathrm{C}: \mathrm{N}$ ratio on the microbial biomass $\mathrm{C}$ concentration $(r=0.16, p>0.05$; Table 2). The incubation temperatures at which the respiration rates had been determined ranged from 14 to $25^{\circ} \mathrm{C}$. $q \mathrm{CO}_{2}$ was positively correlated with the incubation temperature (slope $=0.25, r=0.55, p<0.001$; Table 2). Moreover, the latitude was negatively related with the litter $\mathrm{N}$ concentration $(r=-0.51, p<0.001$; Table 2). Other statistically significant correlations, such as between respiration rate and $q \mathrm{CO}_{2}$, and $\mathrm{N}$ concentration and $\mathrm{C}: \mathrm{N}$ ratio (Table 2), were due to the intrinsic dependence of the variables. No significant relation between the litter $\mathrm{C}: \mathrm{N}$ ratio and the microbial $\mathrm{C}: \mathrm{N}$ ratio was found ( $r=0.11, p>0.05$; Table 2). Unfortunately, only very few studies have reported litter $\mathrm{P}$ or microbial $\mathrm{P}$ concentrations, rendering the inclusion of these parameters into the analysis impossible.

The linear regression model of $q \mathrm{CO}_{2}$ with the $\mathrm{C}: \mathrm{N}$ ratio as the only predicting variable had an $R^{2}=0.61(p<$ 0.001 ). If the incubation temperature was included in the model of $q \mathrm{CO}_{2}$, the $R^{2}$ increased to $R^{2}=0.72(p<0.001)$. The $R^{2}$ slightly increased further if the soil water content was additionally included as a predicting variable (also $R^{2}=$ $0.73, p<0.001)$. If all assessed litter layer properties $(\mathrm{C}: \mathrm{N}$ ratio, temperature, soil water content, $\mathrm{C}, \mathrm{N}, \mathrm{C}_{\text {mic }}, \mathrm{N}_{\text {mic }}$ ) and 


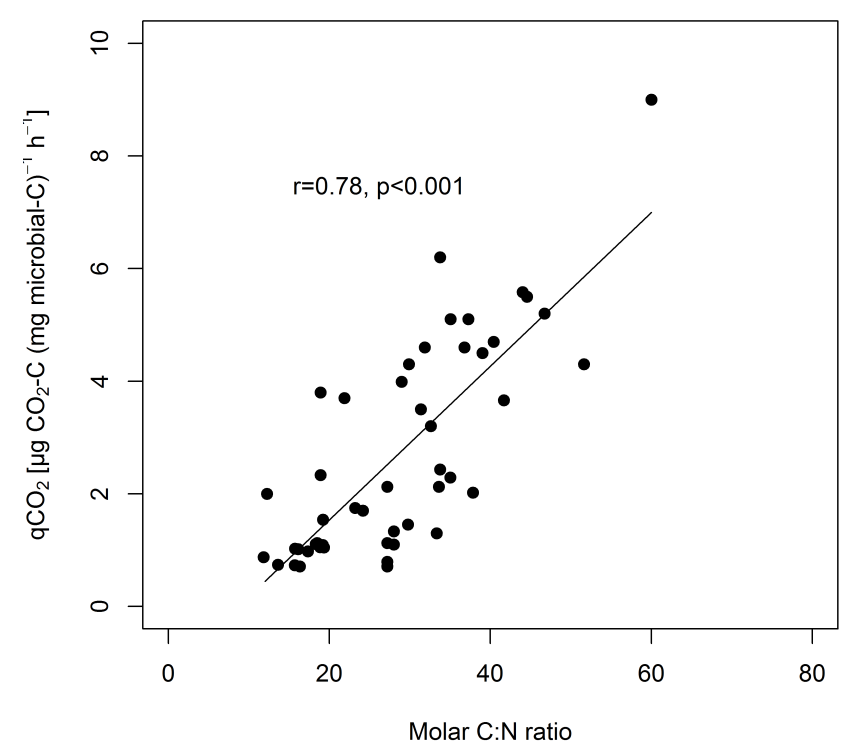

Figure 1. Correlation between the metabolic quotient $\left(q \mathrm{CO}_{2}\right)$ and the molar carbon-to-nitrogen ratio $(\mathrm{C}: \mathrm{N})$ of the soil litter layer.

the latitude were included in the linear model as predicting variables, the $R^{2}$ increased to $R^{2}=0.87(p<0.001)$.

\section{Discussion}

Here it was found that microbial respiration rate both in absolute terms and per unit microbial biomass was positively correlated with the soil litter $\mathrm{C}: \mathrm{N}$ ratio. The findings are in accordance with previous studies that reported a positive correlation between litter layer $\mathrm{C}: \mathrm{N}$ ratio and respiration (Othonen, 1994; Gödde et al., 2002; Michel and Matzner, 2002), and a negative relation between respiration and available $\mathrm{N}$ (Craine et al., 2007). The findings also agree with results from litterbag studies on litter decomposition in relation to litter C: $\mathrm{N}$ ratio (Berg and Matzner, 1997; Berg and McClaugherty, 2003). Moreover, the findings go in line with a positive correlation between $q \mathrm{CO}_{2}$ and the soil C-to-nutrient ratios found recently in beech, spruce, and mixed forests (Spohn and Chodak, 2015).

There are at least three explanations for the observed relationships. A first explanation might be that microorganisms mine litter for $\mathrm{N}$; that is, they burn readily available $\mathrm{C}$ in order to gain energy to acquire $\mathrm{N}$ from more recalcitrant forms of organic matter (Craine et al., 2007) or in order to have physical access to the $\mathrm{N}$ incorporated in organic compounds. However, it can be questioned whether microorganisms that suffer from $\mathrm{N}$ limitation can afford to invest $\mathrm{N}$ into the production of exoenzymes and release them to acquire $\mathrm{C}$, especially in $\mathrm{N}$-poor soils, where the payoff in terms of $\mathrm{N}$ is very small. A second explanation might be overflow respiration, which means that microorganisms uncouple respiration from energy production and only respire $\mathrm{C}$ to dispose it of (Russel

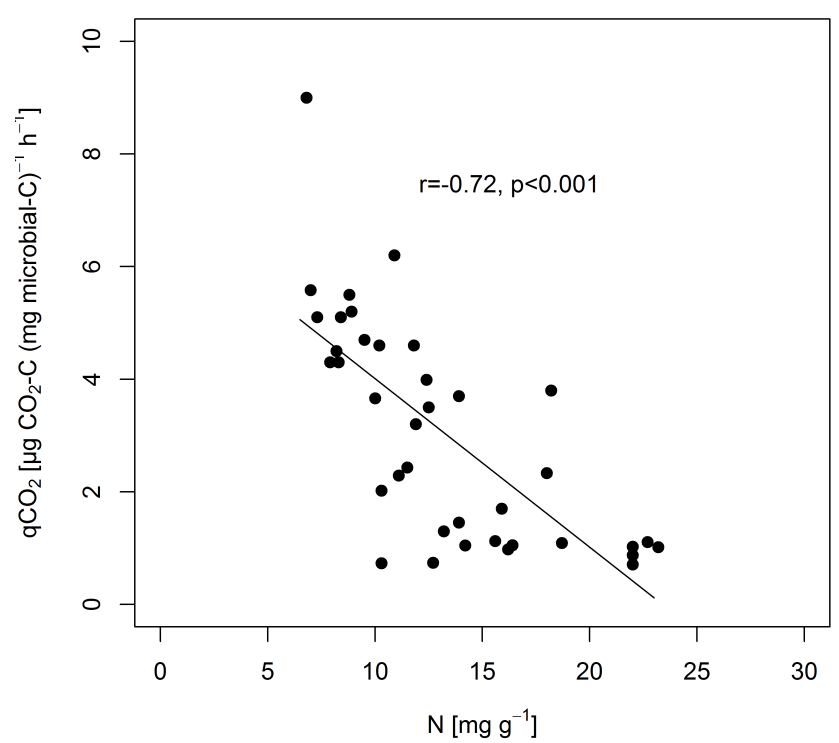

Figure 2. Correlation between the metabolic quotient $\left(q \mathrm{CO}_{2}\right)$ and the soil litter layer nitrogen $(\mathrm{N})$ concentration.

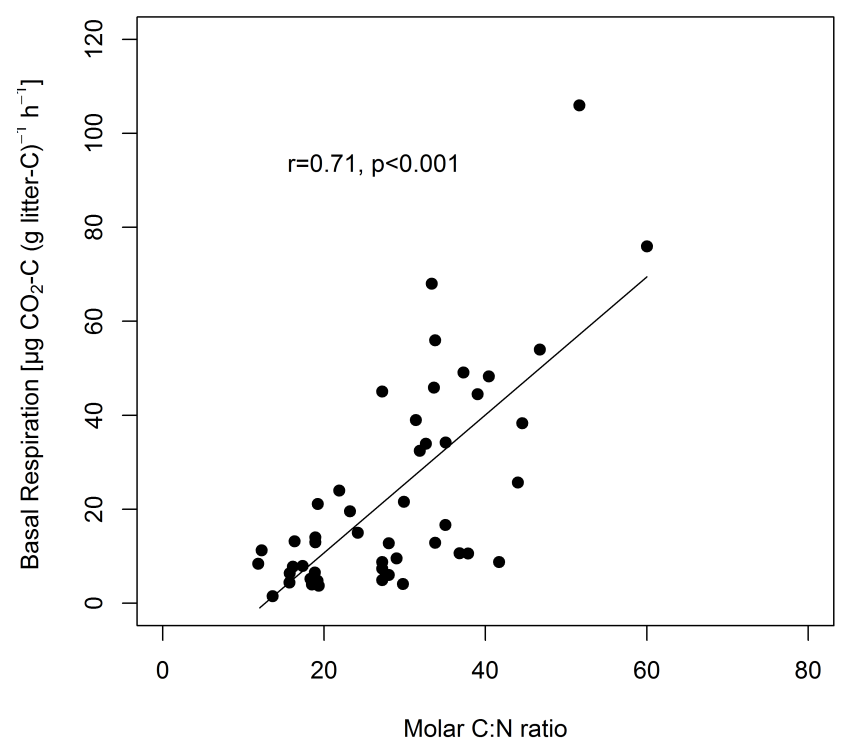

Figure 3. Correlation between the basal respiration rate and the molar carbon-to-nitrogen ratio $(\mathrm{C}: \mathrm{N})$ of the soil litter layer.

and Cook et al., 1995; Manzoni et al., 2008, 2010). Overflow respiration has been observed in many microbial species in lab incubations (Russell and Cooks 1995; Teixeira de Mattos and Neijssel, 1997). However, the relevance of microbial overflow respiration in ecosystems has been questioned for two reasons (Hessen and Anderson, 2008). First, the disposal of $\mathrm{C}$ via respiration requires $\mathrm{N}$ to maintain the proteins of the respiratory chain, and thus it would be more beneficial for microorganisms to dispose of excess $\mathrm{C}$ by releasing DOC (Hessen and Anderson, 2008). Second, microorganisms may use $\mathrm{C}$ that is in surplus to their demands of somatic growth 
for promoting their fitness by $\mathrm{C}$ storage, buildup of structural defenses, viral repellents or establishment of symbiosis. However, it has to be taken into account that the buildup of structural defenses, viral repellents or establishment of symbiosis also requires $\mathrm{N}$ and that there are limits to the amounts of $\mathrm{C}$ that microbes can store and likely also to the amounts of $\mathrm{C}$ microbes can invest into buildup of structural defenses, viral repellents or establishment of symbiosis. A third explanation for decreased respiration at low litter $\mathrm{C}: \mathrm{N}$ ratios could be that the activity of oxidative enzymes involved in the degradation of aromatic compounds decreases with increasing N concentration (Carreiro et al., 2000; Saya-Cork et al., 2002; Michel and Matzner, 2003; Gallo et al., 2004). Decreased lignolytic activity might decrease microbial respiration in litter with low C: $\mathrm{N}$ ratios (Carreiro et al., 2000; Eiland et al., 2001; Saya-Cork et al., 2002). All three mechanisms - $\mathrm{N}$ mining, overflow respiration, and enzyme inhibition - could explain the observed relationship between $q \mathrm{CO}_{2}$ and the litter layer $\mathrm{C}: \mathrm{N}$ ratio. Based on the data presented here it cannot be concluded as to which of the three mechanisms is most relevant to the observed relationships.

The positive relationship between the incubation temperature and $q \mathrm{CO}_{2}$ indicates that $q \mathrm{CO}_{2}$ increases with temperature. This influence of the temperature on $q \mathrm{CO}_{2}$ is supported by the higher $R^{2}$ of the model of $q \mathrm{CO}_{2}$ as a function of the $\mathrm{C}: \mathrm{N}$ ratio and temperature $\left(R^{2}=0.72\right)$ compared to the model of $q \mathrm{CO}_{2}$ as a function of only the $\mathrm{C}: \mathrm{N}$ ratio $\left(R^{2}=0.61\right)$. The finding that $q \mathrm{CO}_{2}$ increased with temperature is in accordance with Xu et al. (2006).

The findings about the litter layer stoichiometry and $q \mathrm{CO}_{2}$ seem to be in agreement with findings about the microbial carbon use efficiency. With increasing litter $\mathrm{C}: \mathrm{N}$ ratio, microbial carbon use efficiency decreases because the microorganisms do not have enough $\mathrm{N}$ to build up as much biomass as the C concentration would allow them (Manzoni et al., 2010; Cotrufo et al., 2013; Sinsabaugh et al., 2013). This seems to agree with the positive correlation between $q \mathrm{CO}_{2}$ and the litter $\mathrm{C}: \mathrm{N}$ ratio. However, it has to be taken into account that $q \mathrm{CO}_{2}$ cannot be directly converted into carbon use efficency since $q \mathrm{CO}_{2}$ is the ratio of a flux and a pool and carbon use efficency is a ratio of two fluxes, or in other words since $q \mathrm{CO}_{2}$ does not tell how much $\mathrm{C}$ was taken up by the microorganisms. Thus, based on the findings presented here, no conclusions about microbial carbon use efficiency can be drawn.

One further way in which microorganisms can react to imbalanced substrate stoichiometry is to gradually adjust the microbial biomass stoichiometry to the substrate as recently shown for microorganisms in tropical litter (Fanin et al., 2013). However, in this study, I did not find a significant relation between the litter $\mathrm{C}: \mathrm{N}$ ratio and the microbial $\mathrm{C}: \mathrm{N}$ ratio, indicating that the microbial community did not adapt its biomass composition to the litter layer stoichiometry.

There are several implications of the relationships found here. The positive correlation between $q \mathrm{CO}_{2}$ and litter $\mathrm{C}: \mathrm{N}$ ratio resulted from an increase in respiration with the $\mathrm{C}: \mathrm{N}$ ratio in combination with no significant effect of the litter $\mathrm{C}: \mathrm{N}$ ratio on the soil microbial biomass $\mathrm{C}$ concentration. The findings of this study indicate that atmospheric $\mathrm{N}$ deposition, leading to decreased litter $\mathrm{C}: \mathrm{N}$ ratios, might decrease microbial respiration in soil litter layers both in absolute terms and per unit microbial biomass. This is in accordance with studies that reported that long-term $\mathrm{N}$ deposition and fertilization, resulting in decreased plant litter $\mathrm{C}: \mathrm{N}$ ratios, increased soil $\mathrm{C}$ sequestration in forests (Magnani et al., 2007; Pregitzer et al., 2008; Janssens et al., 2010). Pregitzer et al. (2008) and Janssens et al. (2010) found that the major reason for the positive effect of $\mathrm{N}$ deposition on $\mathrm{C}$ sequestration is reduced respiration with decreasing soil $\mathrm{C}: \mathrm{N}$ ratio. The present study suggests that this reduction in respiration rates is not due to a lower microbial biomass concentration but instead to a reduced respiration rate per unit microbial biomass. Another implication of the results presented here concerns soil and ecosystem models. In these models, the proportion of $\mathrm{C}$ respired per unit decomposer biomass is usually thought to be constant (Manzoni and Porporato, 2009). However, here it was shown that it is highly dependent on the soil litter layer $\mathrm{C}: \mathrm{N}$ ratio.

\section{Conclusions}

This analysis of literature data shows that microbial respiration both in absolute terms and per unit microbial biomass in soil litter layers increases with the litter $\mathrm{C}: \mathrm{N}$ ratio, highlighting the importance of soil stoichiometry for microbial mineralization processes. The findings indicate that atmospheric $\mathrm{N}$ deposition, leading to decreased litter $\mathrm{C}: \mathrm{N}$ ratios, might decrease microbial respiration in soils.

Acknowledgements. I would like to thank Egbert Matzner, Rainer G. Joergensen, and Carlos A. Sierra for constructive comments on previous versions of this manuscript.

Edited by: T. Keenan

\section{References}

Anderson, T. H. and Domsch, K. H.: The metabolic quotient for $\mathrm{CO}_{2}\left(q \mathrm{CO}_{2}\right)$ as a specific activity parameter to assess the effects of environmental conditions, such as $\mathrm{pH}$, on the microbial biomass of forest soils, Soil Biol. Biochem., 25, 393-395, 1993.

Anderson, T. H. and Domsch, K. H.: Soil microbial biomass: the eco-physiological approach, Soil Biol. Biochem., 42, 20392043, 2010.

Bastida, F., Zsolnay, A., Hernández, T., and García, C.: Past, present and future of soil quality indices: a biological perspective, Geoderma, 147, 159-171, 2008 
Berg, B. and Matzner, E.: Effect of $\mathrm{N}$ deposition on decomposition of plant litter and soil organic matter in forest systems, Environ. Rev., 5, 1-25, 1997.

Berg, B. and McClaugherty, C.: Plant litter: decomposition, humus formation, carbon sequestration 1st Edn. Springer-Verlag, Berlin, Germany, 2003.

Brookes, P. C.: The use of microbial parameters in monitoring soil pollution by heavy-metals, Biol. Fertil. Soils, 19, 269-279, 1995.

Carreiro, M. M., Sinsabaugh, R. L., Repert, D. A., and Parkhurst, D.F.: Microbial enzyme shifts explain litter decay responses to simulated nitrogen deposition, Ecology, 81, 2359-2365, 2002.

Cebrian, J.: Patterns in the fate of production in plant communities, The American Naturalist, 154, 449-468, 1999.

Chang, S. X. and Trofymow, J. A.: Microbial respiration and biomass (substrate-induced respiration) in soils of old-growth and regenerating forests on northern Vancouver Island, British Columbia, Soil Biol. Biochem., 23, 145-152, 1996.

Chapman, S. J., Campbell, C. D., and Puri, G.: Native woodland expansion: soil chemical and microbiological indicators of change, Soil Biol. Biochem., 35, 753-764, 2003.

Cleveland, C. C. and Liptzin, D.: C: $\mathrm{N}: \mathrm{P}$ stoichiometry in soil: is there a "Redfield ratio" for the microbial biomass? Biogeochemistry, 85, 235-252, 2007.

Cotrufo, M. F., Wallenstein, M. D., Boot, C. M., Denef, K., and Paul, E.: The Microbial Efficiency-Matrix Stabilization (MEMS) framework integrates plant litter decomposition with soil organic matter stabilization: do labile plant inputs form stable soil organic matter?, Global Change Biol., 19, 988-995, 2913.

Craine, J. M., Morrow, C., and Fierer, N.: Microbial nitrogen limitation increases decomposition, Ecology, 88, 2105-2113, 2007.

Dinesh, R., Suryanarayana, M. A., Chaudhuri, S. G., Sheeja, T. E., and Shiva, K. N.: Long-term effects of leguminous cover crops on biochemical and biological properties in the organic and mineral layers of soils of a coconut plantation, Eur. J. Soil Biol., 42, 147-157, 2006.

Eiland, F., Klamer, M., Lind, A. M., Leth, M., and Baath, E.: Influence of initial $\mathrm{C} / \mathrm{N}$ ratio on chemical and microbial composition during long term composting of straw, Microb. Ecol., 41, 272280, 2001.

Fanin, N., Fromin, N., Buatois, B., and Hättenschwiler, S.: An experimental test of the hypothesis of non-homeostatic consumer stoichiometry in a plant litter-microbe system, Ecol. Lett., 16, 764-772, 2013.

Fisk, M. C. and Fahey, T. J.: Microbial biomass and nitrogen cycling responses to fertilization and litter removal in young northern hardwood forests, Biogeochemistry, 53, 201-223, 2001.

Gallo, M., Amonette, R., Lauber, C., Sinsabaugh, R. L., and Zak, D. R.: Microbial community structure and oxidative enzyme activity in nitrogen-amended north temperate forest soils, Microb. Ecol., 48, 218-229, 2004.

Gödde, M., David, M. B., Christ, M. J., Kaupenjohann, M., and Vance, G. F.: Carbon mobilization from the forest floor under red spruce in the northeastern USA, Soil Biol. Biochem., 28, 11811189, 1996.

Hessen, D. O. and Anderson, T. R.: Excess carbon in aquatic organisms and ecosystems: physiological, ecological, and evolutionary implications, Limnol. Oceanogr., 53, 1685-1696, 2008.
Hessen, D. O., Elser, J. J., Sterner, R. W., and Urabe, J.: Ecological stoichiometry: An elementary approach using basic principles, Limnol. Oceanogr., 58, 2219-2236, 2013.

Janssens, I., Dieleman, W., Luyssaert, S. Subke, J.-A., Reichstein, M., Ceulemans, R., Ciais, P., Dolman, A. J., Grace, J., Matteucci, G., Papale, D., Piao, L., Schulze, E. D., Tang, J., and Law, B.W.: Reduction of forest soil respiration in response to nitrogen deposition, Nat. Geosci., 3, 315-322, 2010.

Kanerva, S. and Smolander, A.: Microbial activities in forest floor layers under silver birch, Norway spruce and Scots pine, Soil Biol. Biochem., 39, 1459-1467, 2007.

Magnani, F., Mencuccini, M., Borghetti, M., Berbigier, P., Berninger, F., Delzon, S., Grelle, A., Hari, P., Jarvis, P. G., Kolari, P., Kowalski, A. S., Lankreijer, H., Law, B. E., Lindroth, A., Loustau, A., Manca, G. M., Moncrieff, J. B., Rayment, M., Tedeschi, C., Valentini, R., and Grace, J.: The human footprint in the carbon cycle of temperate and boreal forests, Nature, 447 , 849-851, 2007.

Manzoni, S., Jackson, R. B., Trofymow, J. A., and Porporato, A.: The global stoichiometry of litter nitrogen mineralization, Science, 321, 684-686, 2008.

Manzoni, S. and Porporato, A.: Soil carbon and nitrogen mineralization: theory and models across scales, Soil Biol. Biochem., 41, 1355-1379, 2009.

Manzoni, S., Trofymow, J. A., Jackson, R. B., and Porporato, A.: Stoichiometric controls on carbon, nitrogen, and phosphorus dynamics in decomposing litter, Ecol. Monogr., 80, 89-106, 2010.

Michel, K. and Matzner, E.: Nitrogen content of forest floor Oa layers affects carbon pathways and nitrogen mineralization, Soil Biol. Biochem., 34, 1807-1813, 2002.

Michel, K. and Matzner, E.: Response of enzyme activities to nitrogen addition in forest floors of different C-to-N ratios, Biol. Fertil. Soils, 38, 102-109, 2003.

Ndaw, S. M., Gama-Rodrigues, A. C., Gama-Rodrigues, E. F., Sales, K. R. N., and Rosado, A. S.: Relationships between bacterial diversity, microbial biomass, and litter quality in soils under different plant covers in northern Rio de Janeiro State, Brazil, Can. J. Microbiol., 55, 1089-1095, 2009.

Ohtonen, R.: Accumulation of organic matter along a pollution gradient: application of Odum's theory of ecosystem energetics, Microb. Ecol., 27, 43-55, 1994.

Pietikäinen, J. and Fritze, H.: Clear-cutting and prescribed burning in coniferous forest: comparison of effects on soil fungal and total microbial biomass, respiration activity and nitrification, Soil Biol. Biochem., 27, 101-109, 1995.

Pregitzer, K. S., Burton, A. J., Zak, D. R., and Talhelm, A. F.: Simulated chronic nitrogen deposition increases carbon storage in Northern Temperate forests, Global Change Biol., 14, 142-153, 2008.

R Core Team R: A language and environment for statistical computing R Foundation for Statistical Computing, Vienna, Austria, 2013.

Redfield, A. C.: On the proportions of organic derivations in sea water and their relation to the composition of plankton, in: James Johnstone Memorial Volume, edited by: Daniel, R. J. University Press of Liverpool, Liverpool, 177-192, 1934.

Ross, D. J. and Sparling, G. P.: Comparison of methods to estimate microbial $\mathrm{c}$ and $\mathrm{n}$ in litter and soil under pinus radiate on a coastal sand, Soil Biol. Biochem., 25, 1591-1599, 1993. 
Ross, D. J. and Tate, K. R.: Microbial C and N in litter and soil of a southern beech Nothofagus forest: Comparison of measurement procedures, Soil Biol. Biochem., 25, 467-475, 1993.

Ross, D. J., Tate, K. R., and Feltham, C. W.: Microbial biomass, and $\mathrm{C}$ and $\mathrm{N}$ mineralization, in litter and mineral soil of adjacent montane ecosystems in a southern beech Nothofagus forest and a tussock grassland, Soil Biol. Biochem., 28, 1613-1620, 1996.

Ross, D. J., Kelliher, F. M., and Tate, K. R.: Microbial processes in relation to 31 carbon, nitrogen and temperature regimes in litter and a sandy mineral soil from a central Siberian Pinus sylvestris L. forest, Soil Biol. Biochem., 31, 757-767, 1999a.

Ross, D. J., Tate, K. R., Scott, N. A., and Feltham, C. W.: Land-use change: effects on soil carbon, nitrogen and phosphorus pools and fluxes in three adjacent ecosystems, Soil Biol. Biochem., 31, 803-813, 1999b.

Russell, J. B. and Cook, G. M.: Energetics of bacterial growth: balance of anabolic and catabolic reactions, Microbiol. Rev., 59, 4862, 1995.

Saiya-Cork, K. R., Sinsabaugh, R. L., and Zak, D. R.: The effects of long term nitrogen deposition on extracellular enzyme activity in an Acer saccharum forest soil, Soil Biol. Biochem., 34, 13091315, 2002.

Schimel, J. P., Gulledge, J. M., Clein-Curley, J. S., Lindstrom, J. E., and Braddock, J. F.: Moisture effects on microbial activity and community structure in decomposing birch litter in the Alaskan taiga, Soil Biol. Biochem., 31, 831-838, 1999.

Sinsabaugh, R. L., Manzoni, S., Moorhead, D. L., and Richter, A.: Carbon use efficiency of microbial communities: stoichiometry, methodology and modelling, Ecol. Lett., 16, 930-939, 2013.
Spohn, M. and Chodak, M.: Microbial respiration per unit biomass increases with carbon-to-nutrient ratios in forest soils, Soil Biol. Biochem., 81, 128-133, 2015.

Sterner, R. W. and Elser, J. E.: Ecological Stoichiometry: The Biology of Elements from Molecules to the Biosphere, Princeton University Press, Princeton, 1-43, 2002.

Teixeira de Mattos, M. and Neijssel, O. M.: Bioenergetic consequences of microbial adaptation to low-nutrient environments, J. Biotech., 59, 117-126, 1997.

Tummers, B.: DataThief III, http://datathief.org/ (last access: 20 January 2014), 2006.

van Meeteren, M. J. M., Tietema, A., and Westerveld, J. W.: Regulation of microbial carbon, nitrogen, and phosphorus transformations by temperature and moisture during decomposition of Calluna vulgaris litter, Biol. Fertil. Soils, 44, 103-112, 2007.

Vemuri, G. N., Altman, E., Sangurdekar, D. P., Khodursky, A. B., and Eiteman, M. A.: Overflow metabolism in Escherichia coli during steady-state growth: transcriptional regulation and effect of the redox ratio, Appl. Environ. Microbiol., 72, 3653-3661, 2006.

$\mathrm{Xu}, \mathrm{X}$., Inubushi, K., and Sakamoto, K.: Effect of vegetation and temperature on microbial biomass carbon and metabolic quotients of temperate volcanic forest soils, Geoderma, 136, 310 319, 2006.

Xu, X., Thornton, P. E., and Post, W. M.: A global analysis of soil microbial biomass carbon, nitrogen and phosphorus in terrestrial ecosystems, Global Ecol. Biogeogr., 22, 737-749, 2013. 